\title{
External forcings, oceanographic processes and particle flux dynamics in Cap de Creus submarine canyon, NW Mediterranean Sea
}

\author{
A. Rumín-Caparrós ${ }^{1}$, A. Sanchez-Vidal ${ }^{1}$, A. Calafat ${ }^{1}$, M. Canals ${ }^{1}$, J. Martín ${ }^{2}$, P. Puig ${ }^{2}$, and R. Pedrosa-Pàmies ${ }^{1}$ \\ ${ }^{1}$ GRC Geociències Marines, Dept. d'Estratigrafia, Paleontologia i Geociències Marines, Universitat de Barcelona, \\ 08028 Barcelona, Spain \\ ${ }^{2}$ Institut de Ciències del Mar (CSIC), Passeig Marítim de la Barceloneta 37-49, 08003, Barcelona, Spain
}

Correspondence to: A. Sanchez-Vidal (anna.sanchez@ub.edu)

Received: 29 November 2012 - Published in Biogeosciences Discuss.: 18 December 2012

Revised: 12 March 2013 - Accepted: 23 April 2013 - Published: 3 June 2013

\begin{abstract}
Particle fluxes (including major components and grain size), and oceanographic parameters (near-bottom water temperature, current speed and suspended sediment concentration) were measured along the Cap de Creus submarine canyon in the Gulf of Lions (GoL; NW Mediterranean Sea) during two consecutive winter-spring periods (2009-2010 and 2010-2011). The comparison of data obtained with the measurements of meteorological and hydrological parameters (wind speed, turbulent heat flux, river discharge) have shown the important role of atmospheric forcings in transporting particulate matter through the submarine canyon and towards the deep sea.

Indeed, atmospheric forcing during 2009-2010 and 2010-2011 winter months showed differences in both intensity and persistence that led to distinct oceanographic responses. Persistent dry northern winds caused strong heat losses $\left(14.2 \times 10^{3} \mathrm{~W} \mathrm{~m}^{-2}\right)$ in winter 2009-2010 that triggered a pronounced sea surface cooling compared to winter 2010-2011 (1.6 $\times 10^{3} \mathrm{~W} \mathrm{~m}^{-2}$ lower). As a consequence, a large volume of dense shelf water formed in winter 20092010 , which cascaded at high speed (up to $\sim 1 \mathrm{~m} \mathrm{~s}^{-1}$ ) down Cap de Creus Canyon as measured by a currentmeter in the head of the canyon. The lower heat losses recorded in winter 2010-2011, together with an increased river discharge, resulted in lowered density waters over the shelf, thus preventing the formation and downslope transport of dense shelf water.

High total mass fluxes (up to $84.9 \mathrm{~g} \mathrm{~m}^{-2} \mathrm{~d}^{-1}$ ) recorded in winter-spring 2009-2010 indicate that dense shelf wa-
\end{abstract}

ter cascading resuspended and transported sediments at least down to the middle canyon. Sediment fluxes were lower $\left(28.9 \mathrm{~g} \mathrm{~m}^{-2} \mathrm{~d}^{-1}\right)$ under the quieter conditions of winter 2010-2011. The dominance of the lithogenic fraction in mass fluxes during the two winter-spring periods points to a resuspension origin for most of the particles transported down canyon. The variability in organic matter and opal contents relates to seasonally controlled inputs associated with the plankton spring bloom during March and April of both years.

\section{Introduction}

Atmospheric-ocean interactions play a key role in the modification of oceanographic processes. Shifts in wind regime and air temperature are among the most important forcing variables in the atmosphere, triggering modifications in thermohaline properties of water, and therefore, in the hydrographic configuration of the upper part of the water column. There are several mechanisms that can transport and mix these atmospheric-modified shallow waters with intermediate or even deep waters. For example, cooling, evaporation or freezing in the surface layer of shallow areas of the continental shelf trigger the formation of dense water that eventually spills over the shelf edge onto the continental slope (see Ivanov et al., 2004, for a review). This causes the transmission of the atmospheric signal from shallow to deep waters within a short time range. 
In the Gulf of Lions (GoL) there are three major mechanisms by which superficial waters are modified and transported from the surface to deep sea regions.

The first is storm-induced downwelling. This is related to the occurrence of E-SE winds that cause increased wave height and shelf sediment resuspension. The excess of water and suspended sediment piled in the inner shelf of the GoL, together with the reinforcement of the coastal current, forces shelf waters to flow towards the southwest and sink mainly through the Cap de Creus Canyon (Palanques et al., 2008). Furthermore, E-SE winds transfer humid marine air towards the coastal relief, where the air is obstructed and results in orographic rainfall and an increase in river discharge. The delivery of riverine particles and the increased shelf sediment resuspension during E-SE storms augments the export of suspended sediments towards the deep sea (Palanques et al., 2006, 2008; Guillén et al., 2006; Sanchez-Vidal et al., 2012).

The second mechanism is dense shelf water cascading (DSWC). This is linked to cold, dry, and persistent $\mathrm{N}-\mathrm{NW}$ winds that induce sea-atmosphere heat losses and mixing of shelf waters (Millot, 1990). As a result, shelf waters become dense and sink, overflowing the shelf edge, and cascade downslope (preferentially through submarine canyons) until they reach their equilibrium depth (Durrieu de Madron et al., 2005).

Both mechanisms (i.e., E-SE storms and DSWC) can occur separately or in parallel, and are responsible for the remobilization and transport of sediments to the deep sea (Canals et al., 2006; Heussner et al., 2006; Palanques et al., 2006, 2008; Puig et al., 2008) and the variability in the biogeochemical composition of settling particles (Sanchez-Vidal et al., 2009; Pasqual et al., 2010). The occurrence of these events represents an important source of food to the deep ecosystems and influences the ecology of its deep-sea populations, as described, for instance, by Company et al. (2008) and Pusceddu et al. (2010). Furthermore, these events contribute to the transport and dispersion of persistent organic pollutants in the marine continental GoL shelf and open seawaters (Salvadó et al., 2012).

The third mechanism is deep-intermediate convection (MEDOC Group, 1970), which is caused again by the occurrence of cold, dry, and persistent N-NW winds that induce a heat and buoyancy loss of offshore waters in the Gulf of Lions, the Ligurian Sea and the Catalan Sea (Schroeder et al., 2010). This leads to mixing at great depths and homogenization of the water column in open sea regions. Recent studies have also documented the potential of such atmospheric-driven phenomena to remobilize sediments at depths below $2000 \mathrm{~m}$ in the northwestern Mediterranean basin (Martín et al., 2010).

With the aim of investigating the relationship between atmospheric forcings and the oceanographic processes and near-bottom particle fluxes, two mooring lines were deployed during two consecutive winter-spring periods (2009-
2010 and 2010-2011) in the Cap de Creus Canyon at $300 \mathrm{~m}$ and $1000 \mathrm{~m}$ water depths. After three decades of year-round continuous monitoring of hydrosedimentary processes in the western GoL, and after considering several studies from both in situ observations (e.g. Canals et al., 2006; Heussner et al., 2006; Palanques et al., 2008; Puig et al., 2008) and numerical modeling (e.g. Ulses et al., 2008a, b), it appears that the most dynamic period in terms of water, sediment and organic matter export are the winter and early spring months. This is the time when dense shelf water forms and cascades downslope, occasional eastern storms occur, and the most prominent yearly planktonic bloom takes place (Fabres et al., 2008; Pasqual et al., 2010). For these reasons, the experiment described here focuses on these months and combines atmospheric data (wind speed and direction, air temperature and heat fluxes) with measured physical parameters (near-bottom temperature and current speed) and particle fluxes (total mass and main components) to assess the atmospheric variables that govern sediment transport to the deep sea floor during these two winter-spring periods. The manuscript is structured as follows: in Sect. 2 the hydrological and oceanographic settings of study area are presented. Material and methods are presented in Sect. 3. Section 4 describes data on the external forcings during the studied period (atmospheric conditions, river discharge, wave height and chlorophyll $a$ concentration), and particle flux and oceanographic data obtained with the sediment traps and the current meters. Section 5 compares all data obtained and discusses the role of atmospheric forcing in the transport of particulate matter through the Cap de Creus submarine canyon. Finally, Sect. 6 contains the main conclusions of the study.

\section{Study area}

The GoL is a river-dominated micro-tidal continental margin that extends from the Cap Croisette, in the northeastern corner of the GoL, to the Cap de Creus at its southwestern limit (Fig. 1). The main morphological characteristic of its sea floor is its crescent-shaped shelf and the numerous submarine canyons incising the slope and shelf-break. The sea surface circulation in the GoL is linked to the Northern Current (NC), which in the study area manifests itself as a geostrophic jet flowing cyclonically along the slope over the 1000-2000 isobaths (Millot, 1999). The NC is associated with a permanent shelf-slope density front which separates shelf fresh coastal waters, directly influenced by the discharge of the Rhône River, from open-sea waters. Seasonal variations of the structure and intensity of the NC have been observed, with the current being narrower, deeper and more intense during winter (Millot, 1999).

Fresh water inputs into the GoL are mainly from three different hydrographic basins: the Alps in the northern part of the GoL (Rhône River), the Massif Central mountains (Hérault and Orb) and the Pyrenees mountains (Agly, Aude, 


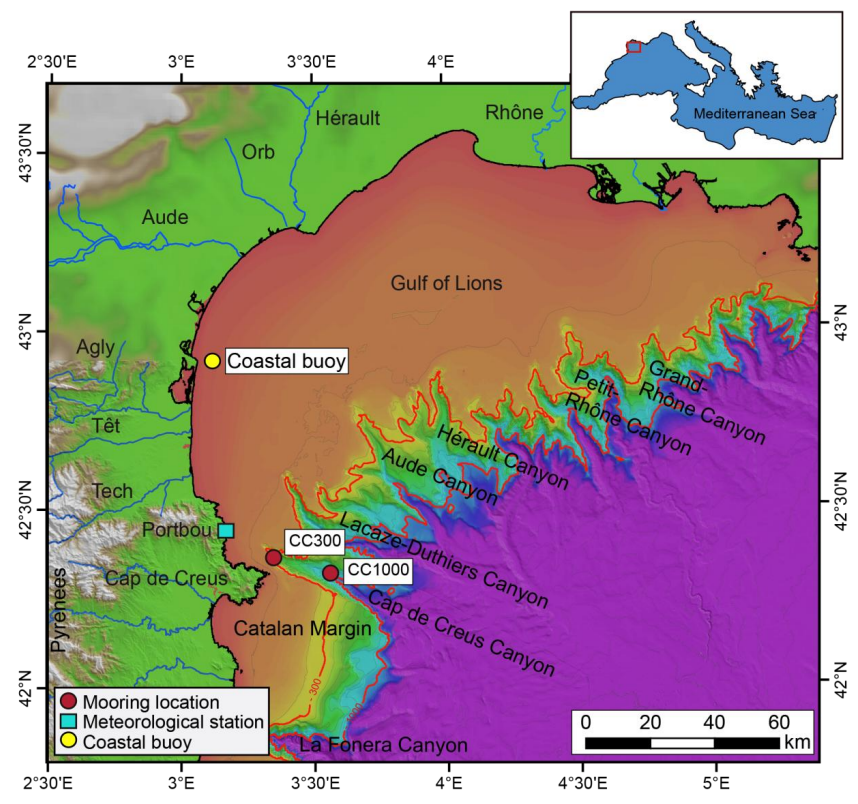

Fig. 1. Topo-bathymetric map of the Cap de Creus Canyon and neighboring areas: the northern Catalan margin at the South and the Gulf of Lions (northwestern Mediterranean) at the North. Locations of moorings (red dots), the meteorological station in Portbou (light blue square) and the Leucate coastal buoy (yellow dot) are shown. Top-right red square indicates where the heat fluxes and Chl $a$ concentration maps have been obtained. Bathymetric data published by Canals et al. (2004).

Tech and Têt rivers). The Rhône River drains much of the water coming from the snowmelt of the Alps and its inputs represent more than the $90 \%$ of the total annual freshwater inputs of the GoL (Bourrin et al., 2006). On the other hand, the Hérault and Orb rivers, and the Agly, Aude, Tech and Têt rivers, drain the Massif Central and the Pyrenees mountains respectively and, unlike the Rhône River, they are mainly controlled by a Mediterranean climatic regime, with short and intense flash flood events (Serrat et al., 2001).

The absence of significant tidal motions makes the combination of the atmospheric forcings (as the prevailing wind fields), the internal dynamics of the currents (and their interaction with the bathymetry) and the main river discharges the major source of variability in the oceanographic parameters of the GoL.

\section{Material and methods}

\subsection{Sample collection and preparation}

Two mooring lines were deployed from November 2009 to May 2010 and from December 2010 to June 2011 along the axis of the Cap de Creus submarine canyon (Fig. 1). Moorings were deployed at the canyon head and upper canyon course (as described by Lastras et al., 2007) at $300 \mathrm{~m}$ and
$1000 \mathrm{~m}$ depth, respectively, and were defined as CC300 and CC1000 according to the deployment depth. Each moored line was equipped with a PPS3 Technicap sequential sampling sediment trap with a $0.125 \mathrm{~m}^{2}$ collecting surface and a 2.5 height/diameter ratio in its cylindrical part (Heussner et al., 1990). Each trap was equipped with 12 receiving cups and was deployed at $25 \mathrm{~m}$ above the bottom with sampling intervals of 15 days. The collecting cups were filled with a buffered $5 \%(v / v)$ formaldehyde solution in $0.45 \mu$ filtered seawater. Each moored line included an Aanderaa RCM9 current meter deployed at $5 \mathrm{~m}$ above the bottom (CC300) and $23 \mathrm{~m}$ above the bottom (CC1000) equipped with a turbidimeter with a sampling interval of $30 \mathrm{~min}$. Turbidity units, recorded in Formazin Turbidity Units (FTU), were transformed into suspended sediment concentrations (SSC) $\left(\mathrm{mg} \mathrm{L}^{-1}\right)$ using the general calibration of Guillén et al. (2000). A technical failure of the current meter deployed at $1000 \mathrm{~m}$ in both years resulted in the complete absence of data at this water depth.

\subsection{Analytical methods}

After recovery, samples were processed according to a modified version of Heussner et al. (1990). Large swimming organisms were removed by wet sieving through a $1 \mathrm{~mm}$ nylon mesh, and organisms of less than $1 \mathrm{~mm}$ were handpicked under a microscope with fine tweezers. Samples were split into aliquots using a high-precision peristaltic pump robot and freeze-dried prior to chemical analysis.

Total carbon, organic carbon, and nitrogen contents were analyzed at "Centres Científics i Tecnològics" of the "Universitat de Barcelona" using an elemental organic analyzer Thermo EA Flash 1112 (Thermo Scientific, Milan, Italy) working in standard conditions recommended by the supplier of the instrument. For the organic carbon analysis, samples were first decarbonated with repeated additions of $100 \mu \mathrm{L}$ of $25 \% \mathrm{HCl}$ until no effervescence was observed. Between each acidification step a $60^{\circ} \mathrm{C}$ drying lapse of $8 \mathrm{~h}$ was carried out. Organic matter $(\mathrm{OM})$ content was calculated as twice the organic carbon content. The inorganic carbon content was calculated as total carbon minus organic carbon and the carbonate content was calculated assuming that all the inorganic carbon is contained within calcium carbonate $\left(\mathrm{CaCO}_{3}\right)$, using the molecular mass ratio of 100/12.

Biogenic silica was analyzed using a two-step $2.5 \mathrm{~h}$ extraction with $0.5 \mathrm{M} \mathrm{Na}_{2} \mathrm{CO}_{3}$ separated by filtration of the leachates. $\mathrm{Si}$ and $\mathrm{Al}$ contents of both leachates were analyzed with an Inductive Coupled Plasma Atomic Emission Spectroscopy (ICP-AES), correcting the Si content of the first leachate by the $\mathrm{Si} / \mathrm{Al}$ ratio of the second one. Once corrected, $\mathrm{Si}$ concentrations were transformed to opal by multiplying by a factor of 2.4 (Mortlock and Froelich, 1989).

The siliciclastic fraction was obtained by subtracting from the total mass the part corresponding to the major biogenic 
components, assuming that the amount of siliciclastics (\%) was $=100-\left(\% \mathrm{OM}+\% \mathrm{CaCO}_{3}+\%\right.$ Opal $)$.

Grain size analyses were performed on a Coulter LS 230 Laser Particle Size Analyzer after organic matter oxidation with $10 \% \mathrm{H}_{2} \mathrm{O}_{2}$.

\subsection{Meteorological, hydrological and oceanographic data}

The exchange of energy between the atmosphere and the sea surface takes place through turbulent and radiative energy fluxes. Mathematically, the net air-sea heat exchange $\left(Q_{\text {net }}\right)$ is the sum of four components:

$Q_{\text {net }}=Q_{\mathrm{sh}}+Q_{\mathrm{lh}}+Q_{\mathrm{sw}}+Q_{\mathrm{lw}}$,

where $Q_{\mathrm{sh}}$ is the sensible heat flux (SHF), $Q_{\mathrm{lh}}$ is the latent heat flux (LHF), $Q_{\text {sw }}$ is the short-wave flux, and $Q_{\text {lw }}$ is the long-wave flux. The sum of the sensible and latent heat fluxes ( $Q_{\mathrm{sh}}+Q_{\mathrm{lh}}$, named turbulent heat flux) is linearly proportional to the wind speed and the air-sea temperature or humidity difference, while the sum of the short-wave and long-wave fluxes ( $Q_{\mathrm{sw}}+Q_{\mathrm{lw}}$, named radiative flux) is function of air temperature, humidity, and cloudiness (Deser et al., 2010).

According to Josey (2003) and Schroeder et al. (2010), LHF, and to a lesser extent SHF, control anomalies in the winter net heat exchanges in the GoL. Both parameters are calculated as follows:

$Q_{\mathrm{sh}}=\rho c_{\mathrm{p}} C_{\mathrm{h}} u\left[T_{\mathrm{s}}-\left(T_{\mathrm{a}}+\gamma z\right)\right]$

$Q_{\mathrm{lh}}=\rho L C_{e} u\left(q_{\mathrm{s}}-q_{\mathrm{a}}\right)$,

where $\rho$ is the air density at observation level, $c_{\mathrm{p}}$ the specific heat capacity of the air at constant pressure, $L$ is the latent heat of evaporation of water, $C_{\mathrm{h}}$ is the transfer coefficient for the SHF, $u$ is the wind speed, $T_{\mathrm{S}}$ and $\mathrm{T}_{\mathrm{a}}$ are the sea surface temperature and the surface air temperature corrected for the adiabatic lapse rate respectively, $\gamma z$ is the height at which the air temperature is measured, $C_{e}$ is the transfer coefficient for the LHF, and $q_{\mathrm{s}}$ and $q_{\mathrm{a}}$ are the specific humidity at the sea surface and the atmospheric specific humidity at the reference level, respectively (Josey et al., 1999). LHF and SHF in the study area have been acquired as part of the activities of NASA's Science Mission Directorate, archived and distributed by the Goddard Earth Sciences (GES) Data and Information Services Center (DISC). The source used has been the Modern Era Retrospective-analysis for Research and Applications (MERRA), which uses the GEOS-5 Data Assimilation System with the adoption of a joint analysis with the National Centers for Environmental Prediction (NCEP) and of a set of physics packages for the atmospheric general circulation model. The study of the sea-atmosphere interactions has been gridded from $42.1^{\circ} \mathrm{N}$ to $43.4^{\circ} \mathrm{N}$; and from $3.1^{\circ} \mathrm{E}$ to $5^{\circ} \mathrm{E}$ (Fig. 1).

Significant wave height $(\mathrm{Hs})$ data have been obtained from the Leucate coastal buoy (Fig. 1), provided by the "Centre
d'Études Techniques Maritimes Et Fluviales" ("Ministère de l'Ecologie, de l'Energie, du Développement durable et de la Mer", CANDHIS, France).

Wind speed and direction have been acquired from the automatic meteorological station in Portbou (see location in Fig. 1), maintained by "Servei Meteorològic de Catalunya" ("Generalitat de Catalunya").

Riverine discharges have been obtained from the "Laboratoire Hydraulique et Mesures" from the Compagnie Nationale du Rhône. The rivers considered are the Rhône River, because it is the main contributor of freshwater inputs of the GoL, and the Hérault, Orb, Agly, Aude, Tech and Têt rivers, in order to consider the freshwater inputs from most of the small rivers discharging into the GoL.

Data on concentration of the photosynthetic pigment Chlorophyll $a(\mathrm{Chl} a$ ) have been obtained from the Goddard Earth Sciences (GES) Data and Information Services Center (DISC), using as a source the Moderate Resolution Imaging Spectoradiometer (MODIS) onboard the Aqua satellite. Chl $a$ concentration is calculated using remotely sensed observations of the ocean surface with visible wavelength data. For our study, Chl $a$ concentration has been gridded, including the mooring location and most of the GoL area (Fig. 1).

\section{Results}

\subsection{External forcings}

Winter 2009-2010 in the Cap de Creus area (northern Catalonia) was characterized by very low temperatures. Air temperatures were approximately $2{ }^{\circ} \mathrm{C}$ lower than the average climatic values registered in the climatic atlas of Catalonia (Martín-Vide and Raso Nadal, 2008). Several wind episodes with severe $\mathrm{N}-\mathrm{NW}$ winds were recorded during late December 2009 (with speeds reaching up to $40 \mathrm{~m} \mathrm{~s}^{-1}$ ), mid-January 2010 (up to $47 \mathrm{~m} \mathrm{~s}^{-1}$ ), and mid-February 2010 (up to $44 \mathrm{~m} \mathrm{~s}^{-1}$ ) (Fig. 2a). At the same time the cumulative turbulent heat losses (LHF and SHF) reached values of $14.2 \times 10^{3} \mathrm{~W} \mathrm{~m}^{-2}$ through the entire winter, from November 2009 until the end of March 2010.

The second winter studied was on average $1{ }^{\circ} \mathrm{C}$ warmer than the previous one. $\mathrm{N}-\mathrm{NW}$ velocities reached speeds of up to $45 \mathrm{~m} \mathrm{~s}^{-1}$ during late December 2010, and up to $42 \mathrm{~m} \mathrm{~s}^{-1}$ in early February 2011 (Fig. 2a). Strong wind events were concentrated in the first half of the winter, so the cumulative turbulent heat loss for the whole winter (from November until the end of March), was $1.6 \times 10^{3} \mathrm{~W} \mathrm{~m}^{-2}$ lower than the previous winter.

Two very important increases in the discharge of rivers draining the Pyrenees and the Massif Central are well distinguished in October 2010 and in March 2011 (Fig. 2c, $3 d)$. During both events the Hérault River reached 40 and $850 \mathrm{~m}^{3} \mathrm{~s}^{-1}$, the Orb River reached 91 and $899 \mathrm{~m}^{3} \mathrm{~s}^{-1}$, the Agly River reached 741 and $635 \mathrm{~m}^{3} \mathrm{~s}^{-1}$, the Aude 


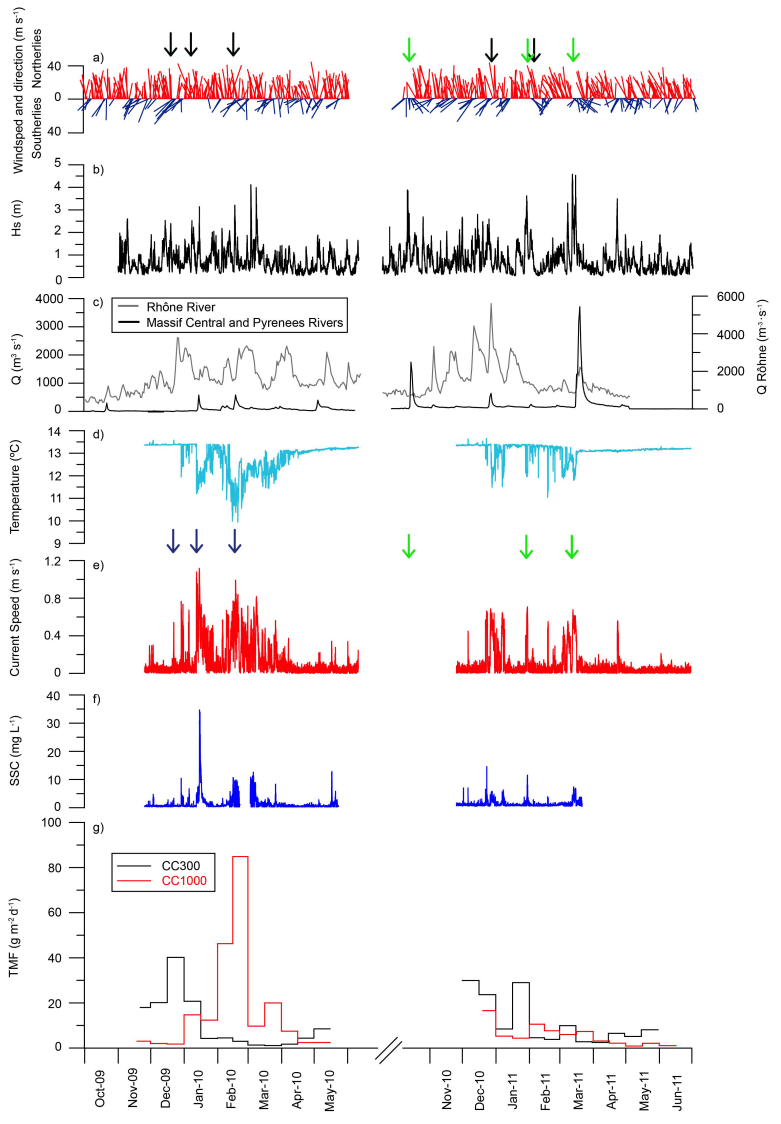

Fig. 2. (a) Temporal variability of northerly winds (red) and southerly winds (blue). Black arrows highlight severe N-NW wind episodes and green arrows the occurrence of eastern storms (b) Significant wave height (Hs); (c) Daily fluvial discharges of the Rhône River in grey and the sum of the main small rivers flowing to the Gulf of Lions (Hérault, Orb, Agly, Aude, Tech and Têt) in black; (d) near-bottom temperature recorded at CC300; (e) near-bottom current speed recorded at $\mathrm{CC} 300$, (f) suspended sediment concentration (SSC) as recorded by the currentmeter at $300 \mathrm{~m}$ of water depth; (g) total mass flux at 300 (black) and $1000 \mathrm{~m}$ (red) of water depth. Blue arrows show period of intense heat losses and DSWC event (as in Figs. 3 and 5), and green arrows the occurrence of eastern storms (as in Fig. 5).

River reached 399 and $561 \mathrm{~m}^{3} \mathrm{~s}^{-1}$, the Tech River 239 and $512 \mathrm{~m}^{3} \mathrm{~s}^{-1}$, and the Têt 245 and $366 \mathrm{~m}^{3} \mathrm{~s}^{-1}$, respectively. Considering that the Rhône river basin is not affected by the Mediterranean climate characterized by its limited rainfall regime (Ludwig et al., 2003), its basal discharge was always very high compared to the rest of the rivers, presenting a much more regular flow rate during the whole period of around $2,000 \mathrm{~m}^{3} \mathrm{~s}^{-1}$ (Figs. 2c, 3e). The higher water discharge in the whole time series was registered at the very end of December 2010, with $5,600 \mathrm{~m}^{3} \mathrm{~s}^{-1}$.

Maximum significant wave height (Hs) was recorded in March in both winters in the context of a reinforcement of easterly winds (Fig. 2a, b), in agreement with larger swell due to the longer fetch distance of $\mathrm{E}$ winds. During winter 2009-2010, the maximum Hs recorded was of $4 \mathrm{~m}$, while during the next winter the maximum Hs was $4.6 \mathrm{~m}$.

Chl $a$ concentration images showed increased pigment concentrations during March, reflecting the well-known seasonal phytoplankton bloom in the region (e.g. Estrada et al., 2011) (Fig. 4).

\subsection{Near-bottom current regime and downward particle fluxes}

Time series of near-bottom water temperature, current speed, near-bottom suspended sediment concentration (SSC) at CC300, and downward total mass flux (TMF) at both CC300 and CC1000, are shown in Fig. 2d-g.

\subsubsection{Winter 2009-2010}

November 2009 was characterized by relatively stable oceanographic conditions at the $\mathrm{CC} 300$ station, with no major changes in near-bottom water temperature and current speeds below $0.29 \mathrm{~m} \mathrm{~s}^{-1}$. At the very end of December 2009 , a drop in near-bottom water temperature (to $11.98^{\circ} \mathrm{C}$ ) was recorded concomitantly with increased current speeds $\left(0.77 \mathrm{~m} \mathrm{~s}^{-1}\right)$ and SSC $\left(10.41 \mathrm{mg} \mathrm{L}^{-1}\right)$. This event lasted a couple of days. At the same time TMF reached $40.2 \mathrm{~g} \mathrm{~m}^{-2} \mathrm{~d}^{-1}$ at $\mathrm{CC} 300$ while no significant increase was recorded at $\mathrm{CC} 1000$.

In mid-January 2010 near-bottom water temperature at CC300 decreased abruptly more than $2{ }^{\circ} \mathrm{C}$ (from 13.40 to $11.21^{\circ} \mathrm{C}$ ), and current speed and SSC increased up to $1.12 \mathrm{~m} \mathrm{~s}^{-1}$ and $34.68 \mathrm{mg} \mathrm{L}^{-1}$, respectively. The lower temperatures and high current speeds were maintained for approximately 16 days. Total mass flux (TMF) at CC300 reached only $20.1 \mathrm{~g} \mathrm{~m}^{-2} \mathrm{~d}^{-1}$ and at $\mathrm{CC} 1000$ increased slightly up to $14.7 \mathrm{~g} \mathrm{~m}^{-2} \mathrm{~d}^{-1}$ (Fig. $2 \mathrm{~g}$ ).

In February 2010 the longer event started, which lasted for one and a half months and was characterized by persistent low bottom water temperature (as low as $9.95^{\circ} \mathrm{C}$ ) and high velocities (up to $0.99 \mathrm{~m} \mathrm{~s}^{-1}$ ). SSC also increased considerably but did not reach the levels of the previous month, being almost 4 times lower. While no variation in TMF was recorded at the $\mathrm{CC} 300$ station, TMF at $\mathrm{CC} 1000$ registered a sharp increase up to values of $84.9 \mathrm{~g} \mathrm{~m}^{-2} \mathrm{~d}^{-1}$.

\subsubsection{Winter 2010-2011}

The second monitored winter presented smaller magnitude anomalies in near-bottom water temperature, current speed and SSC at the CC300 station. At the end of December 2010 water temperature dropped more than $1.5^{\circ} \mathrm{C}$ (to $11.49^{\circ} \mathrm{C}$ ) and current speed increased up to $0.68 \mathrm{~m} \mathrm{~s}^{-1}$ and SSC up to $14.57 \mathrm{mg} \mathrm{L}^{-1}$. These anomalies lasted for 17 days. TMF values at the $\mathrm{CC} 300$ and $\mathrm{CC} 1000$ stations increased up to $23.7 \mathrm{~g} \mathrm{~m}^{-2} \mathrm{~d}^{-1}$ and $16.6 \mathrm{~g} \mathrm{~m}^{-2} \mathrm{~d}^{-1}$, respectively (Fig. $2 \mathrm{~g}$ ). 

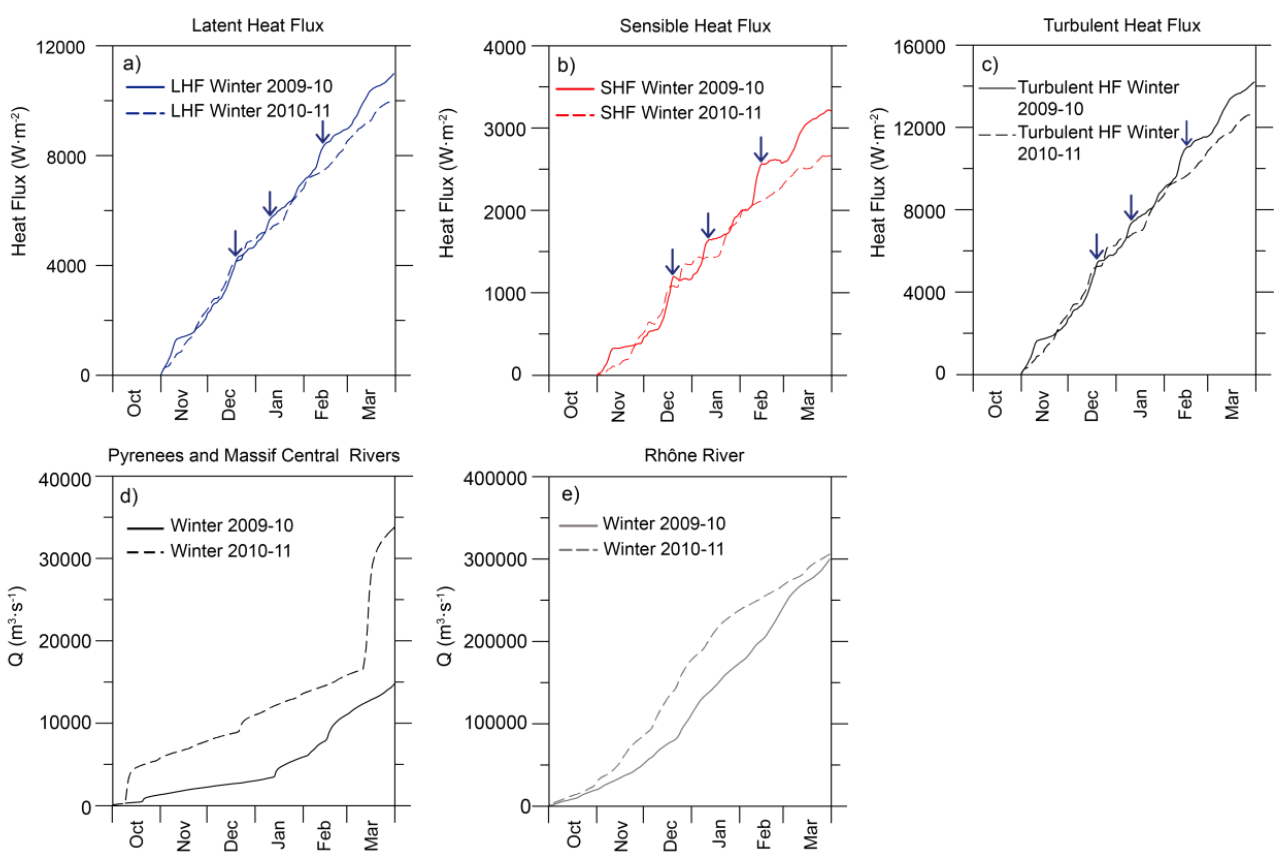

Fig. 3. (a) Cumulated Latent Heat Flux for winter-spring 2009-2010 (continuous line) and 2010-2011 (dashed line); (b) Cumulated Sensible Heat Flux for winter-spring 2009-2010 (continuous line) and 2010-2011 (dashed line); (c) Cumulated Turbulent Heat Flux for winter-spring 2009-2010 (continuous line) and 2010-2011 (dashed line); (d) Cumulated river discharge from the Hérault, Orb, Agly, Aude, Tech and Têt rivers for winters 2009-2010 (continuous line) and 2010-2011 (dashed line); (e) Cumulated river discharge from the Rhône river for winters 2009-2010 (continuous line) and 2010-2011 (dashed line). Blue arrows show period of intense heat losses (as in Figs. 2 and 5).

January and February 2011 were characterized by relatively stable conditions, except for a discrete (lasting less than 2 days) water temperature drop recorded concomitantly with increased current speeds (up to $0.71 \mathrm{~m} \mathrm{~s}^{-1}$ ) recorded at the end of January 2011. At the same time, SSC peaked at $11.53 \mathrm{mg} \mathrm{L}^{-1}$ and TMF at CC300 reached values up to $28.9 \mathrm{~g} \mathrm{~m}^{-2} \mathrm{~d}^{-1}$. No increased TMF was recorded at the CC1000 station.

In March 2011 slight temperature drops (to $11.07^{\circ} \mathrm{C}$ ), increased current speeds $\left(0.68 \mathrm{~m} \mathrm{~s}^{-1}\right)$ and increased SSC (7.37 mg L${ }^{-1}$ ) were again recorded (Fig. $2 \mathrm{~g}$ ). TMF increased slightly at CC300 (up to $9.9 \mathrm{~g} \mathrm{~m}^{-2} \mathrm{~d}^{-1}$ ) and after 15 days at CC1000 (up to $7.3 \mathrm{~g} \mathrm{~m}^{-2} \mathrm{~d}^{-1}$ ) (Fig. $2 \mathrm{~g}$ ).

\subsection{Main components of settling particles}

The temporal variability of the main components (OM, $\mathrm{CaCO}_{3}$, opal and siliciclastics) at the two stations during the winter-spring periods studied is shown in Fig. 5. As repeatedly observed in this region, the siliciclastic component is the main contributor to TMF at all stations and at all depths (Heussner et al., 2006; Pasqual et al., 2010), representing almost $70 \%$ of the total flux. Furthermore, during the second monitored winter-spring 2010-2011, the siliciclastic relative abundance decreased with depth from CC300 to CC1000.

In general the OM relative abundance of TMF during both periods showed a clear temporal variability, display- ing almost always higher concentrations at the CC300 station. During the first period maximum concentration values were recorded during the end of March 2010 at CC300 (up to $4.68 \%$ ) and during late April 2010 at CC1000 (up to $3.42 \%$ ). During the second monitored period, maximum peaks were reached in late February 2011 at CC300 (4.38\%) and late April 2011 in CC1000 (3.61\%).

$\mathrm{CaCO}_{3}$ relative abundance during the first monitored winter-spring period peaked in late January and February 2010 in CC300 and late January 2010 in CC1000, and accounted for up to $30.49 \%$ of the total flux. During the second period values were significantly lower at the CC300 station, increasing in March-April 2011 up to 28.23 and $30.54 \%$ of the CC300 and CC1000 flux.

Opal represented always less than $4 \%$ of the mass flux. During the first monitored winter-spring opal relative abundance increased in December 2009 (up to $1.99 \%$ ) and March-April 2010 (up to $2.01 \%$ ) at both stations. During the second period, the seasonal increase of opal was more evident, increasing in very late April 2011 up to values of $1.93 \%$ at $\mathrm{CC} 300$, and $3.43 \%$ at CC1000.

\subsection{Grain size}

During the two monitored periods, approximately $90 \%$ of the particles were mainly silt-sized (between 4 and $63 \mu \mathrm{m}$ ) 
Winter-Spring 2009-10

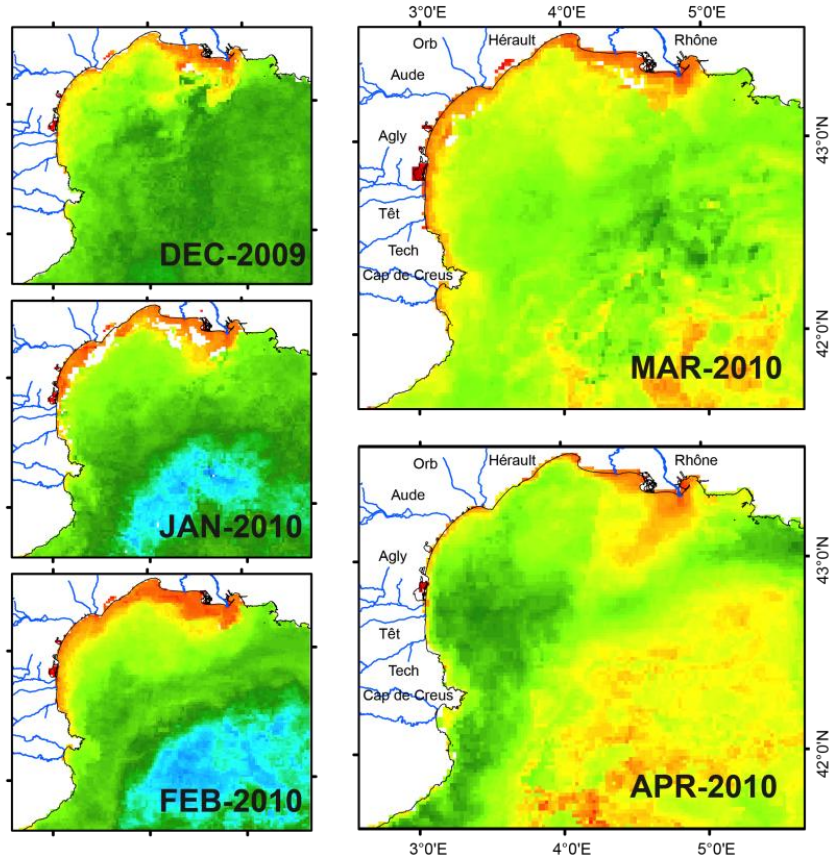

Winter-Spring 2010-11

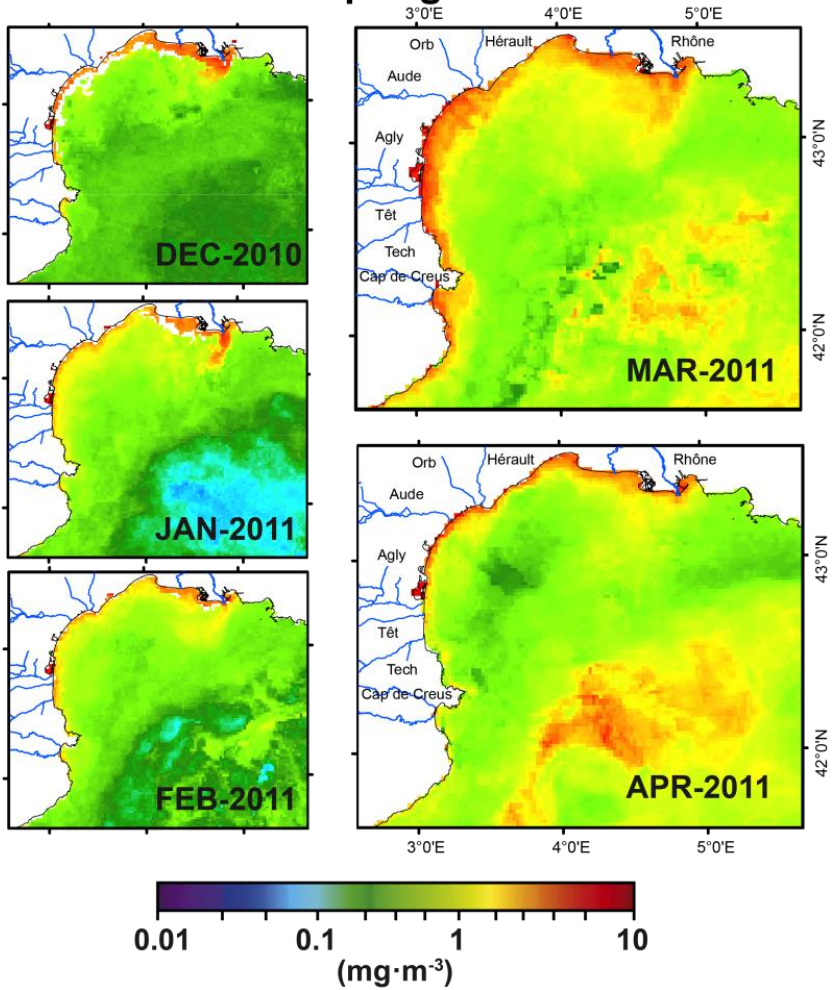

Fig. 4. Sequence of monthly mean Chlorophyll $a$ concentration in the study area during both winter-spring periods.

whereas $10 \%$ of the particles where clay-sized $(<4 \mu \mathrm{m})$. A few samples included sand-sized particles $(>63 \mu \mathrm{m})$.

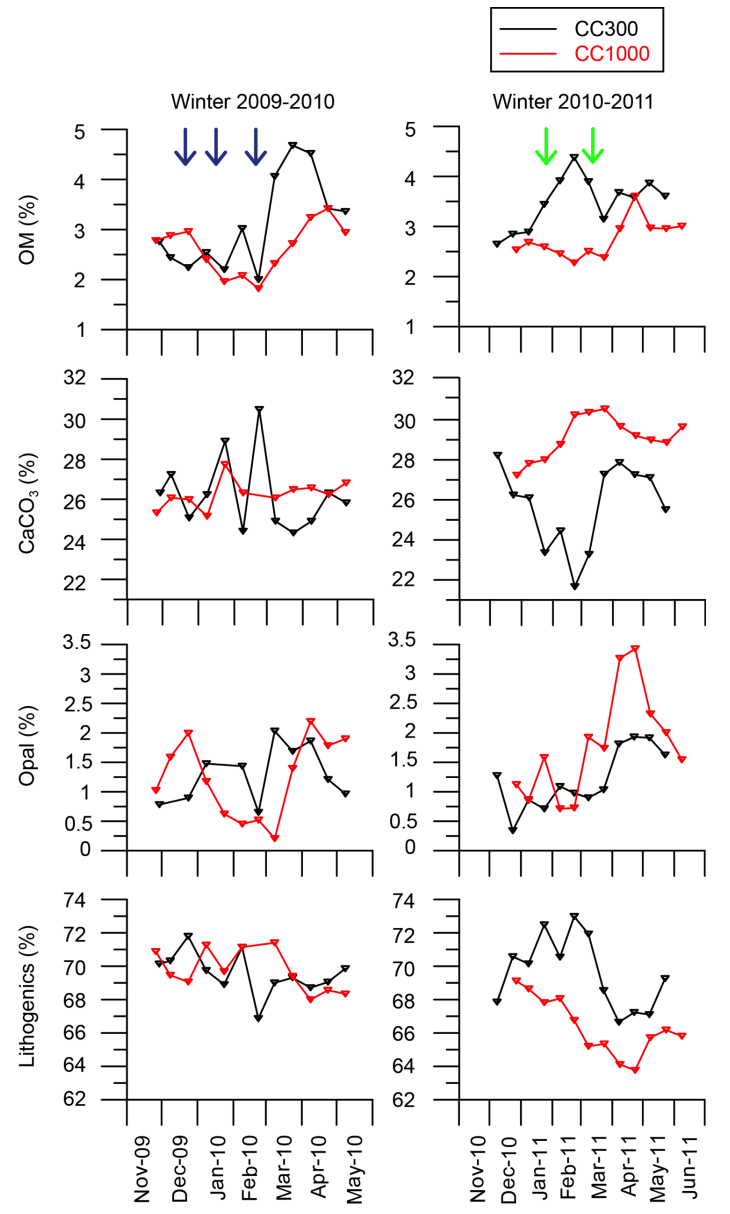

Fig. 5. Temporal variability of the main components of the settling particles $\left(\mathrm{CaCO}_{3}\right.$, Organic Mater (OM), opal and siliciclastics) of the two stations during the two winter-spring periods studied. Black line represents the CC300 station whereas the red line represents the CC1000. (a) Winter-spring 2009-2010. (b) Winter-spring 20102011. Blue arrows show periods of intense heat losses and DSWC event (as in Figs. 2 and 3), and green arrows show eastern storms events (as in Fig. 2).

The grain size distributions display many fluctuations (Fig. 6). During the first winter-spring, the low amount of mass obtained from the sediment cups at CC300 from midJanuary to mid-April 2010 prevented grain size determination. However, the available data show coarsening of the sediments collected during the second half of December 2009 with respect to the samples collected at the beginning and at the end of the evaluated time series (very late November 2009 and early May 2010, respectively). Samples collected during February 2010 in CC1000 also displayed a clear coarsening with respect to the initial and final conditions (Fig. 6a).

During the second winter-spring, smaller changes in the grain size distribution of the sediments collected by the sediment traps were recorded. Nevertheless, the samples 

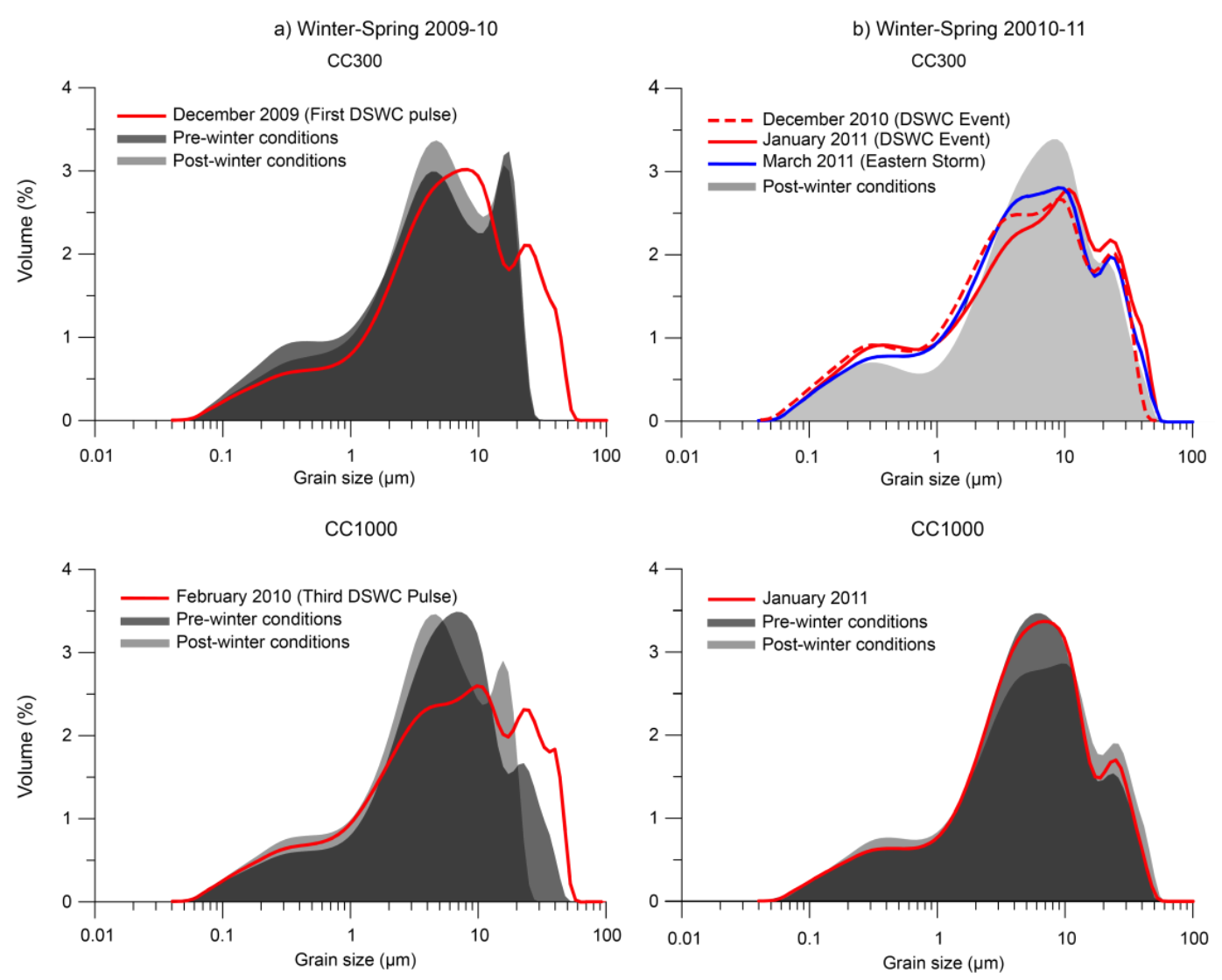

Fig. 6. Grain size distribution of sediment trap samples. Black represents the grain size distribution at the beginning of the winter (initial conditions) and gray the grain size distribution at the end of the winter (final conditions). Red and blue lines represent the grain size distribution during main transport events. (a) Grain size distribution at CC300 and CC1000 during winter 2009-2010. (b) Grain size distribution at CC300 (dashed line for December 2010 DSWC event and continuous line for January 2011 DSWC event) and CC1000 during winter 2010-2011.

collected at CC300 during mid-late January 2011 and during the first half of March 2011 displayed a clear coarsening with respect to the initial and final conditions (end of December 2010 and first half of June 2011, respectively) (Fig. 6b). No remarkable changes were recorded in $\mathrm{CC} 1000$ during the second winter-spring evaluated.

\section{Discussion}

\subsection{Atmospheric forcing of particle fluxes in winter 2009-2010}

Winter 2009-2010 was characterized by the occurrence of several wind storms that triggered important changes in the water column structure and the sediment transport downcanyon. The northern windstorms occurring in December 2009 resulted in strong sea-atmosphere heat losses in the studied area (Fig. 3a-c). Cumulated SHF increased $640 \mathrm{~W} \mathrm{~m}^{-2}$ in less than two weeks (Fig. 3b), which represents an average of sensible heat losses of $58 \mathrm{~W} \mathrm{~m}^{-2}$ per day.
These values are higher than those reported by Schroeder et al. (2010) for "normal" winters in the nearby convection zone, where most extreme heat losses are believed to occur $\left(42-43^{\circ} \mathrm{N}, 4-5^{\circ} \mathrm{E}\right)$. Consequently, at the end of December 2009 shelf waters lost temperature, became denser and sank, overflowing the shelf edge and cascading downslope through the Cap de Creus submarine canyon, as shown by the decrease in near-bottom water temperature at the upper canyon. This process, known as DSWC, has been recently studied in detail in several papers (e.g. Canals et al., 2006; Heussner et al., 2006; Palanques et al., 2006). The DSWC event started in December 2009, lasted for about 2 months and was formed by 3 main pulses of water.

The first DSWC pulse was recorded at the end of December 2009. This event increased down-canyon suspended sediment fluxes mainly by increasing the current speed up to $0.77 \mathrm{~m} \mathrm{~s}^{-1}$ and caused an increase in the TMF up to $40.2 \mathrm{~g} \mathrm{~m}^{-2} \mathrm{~d}^{-1}$ at $\mathrm{CC} 300$ (Fig. 2e, g). In addition, grain size distributions of the particles collected by the sediment trap display a clear coarsening during this pulse (Fig. 6a). This means that the cascading currents were strong enough 
to resuspend and transport coarse particles in suspension from the shelf downwards to the basin. Nevertheless, currents were not strong enough to transport sediment deeper in the canyon, as suggested by the low TMF measured at CC1000. Overall, data suggest that the sediment eroded and transported by the dense water plume settled in somewhere between CC300 and CC1000.

From the end of December 2009 to mid-January 2010, several cold and dry northern windstorms with high wind speeds led to a continued period of heat losses. This sustained heat loss triggered a continued cooling of the surface waters and thus a loss of buoyancy. In consequence, DSWC was reactivated in mid-January, as confirmed by the decrease in the near-bottom water temperature and the sharp increase in the current speed and in the SSC at CC300. The strong intensification in current speed (up to $1.12 \mathrm{~m} \mathrm{~s}^{-1}$ ) and in SSC (up to $34.68 \mathrm{mg} \mathrm{L}^{-1}$ ) denoted a major escape of resuspendible fine sediments from the shelf and down the canyon. Furthermore, the TMF at both CC300 and CC1000 increased slightly, evidencing that, this time, cascading waters reached probably the middle canyon course. In addition, the coarsening of the samples collected during this event at $\mathrm{CC} 1000$ indicates that, effectively, the cascading waters flowed downcanyon, reaching depths of at least $1000 \mathrm{~m}$.

The third DSWC pulse started February 2010. At this stage, the superficial waters of the GoL were probably completely unstratified as a result of the continued wind cooling and mixing processes that took place during the winter. Winter cumulated SHF in the beginning of February was higher than $520 \mathrm{~W} \mathrm{~m}^{-2}$ (note the high slope of SHF in February 2010 Fig. 3b) and the cumulated turbulent heat losses were around $11 \times 10^{3} \mathrm{~W} \mathrm{~m}^{-2}$. This might have caused surface water temperature to decrease, resulting in pronounced buoyancy losses of the coastal waters of the GoL. This situation led shelf waters to cascade downslope continuously for a prolonged time period (from the beginning of February 2010 until the beginning of March 2010), as can be seen by the long and marked drop in near-bottom water temperature (of more than $3^{\circ} \mathrm{C}$ ) and the notable increase in the current speed at the upper canyon (Fig. 2d, e). However, this event resulted in a small increase in down-canyon suspended sediment fluxes at CC300. Guillén et al. (2006) suggested that the "memory" of the past events on the shelf plays a crucial role in sediment dynamics as the recurrence of the preceding storms reduces the availability of fresh shelf sediments that can be resuspended. This also suggests that those events in December 2009 and January 2010 cleaned erodible sediments in the upper canyon and thus cascading waters in February flowed without a significant suspended sediment transport to CC300 (Fig. 2g). However, cascading waters may have eroded part of the sediments trapped between the two moorings in the upper-middle canyon, thus triggering an increased arrival of particles, with the maximum fluxes recorded at the CC1000 station (Fig. 2g). This is also confirmed by the grain size distributions of particles settling dur- ing that event, which repeatedly show coarsening when compared to the pre- and post-winter conditions (Fig. 6a). Overall, the results demonstrate the multi-step sediment transport by cascading pulses, first from the shelf to the upper canyon, and then from the upper canyon to the middle canyon, as observed in winter 2006 by Pasqual et al. (2006) and Palanques et al. (2012). In addition, the arrival of resuspended particles through the southern flank of the canyon may have caused TMF to increase only at middle canyon depths and not at the canyon head (Canals et al., 2006; Martin et al., 2013). Even though with decreasing current speeds (and thus with decreasing capacity of eroding sediments), the DSWC pulse triggered another increase in TMF at the CC1000 station in the end of March 2010, at the very end of the cascading event.

\subsection{Atmospheric forcing of particle fluxes in winter 2010-2011}

An eastern windstorm with high $\mathrm{E}$ winds and $\mathrm{Hs}$ up to $3.9 \mathrm{~m}$ affected the Cap de Creus area in fall 2010. This episode was followed by increased river discharge in the rivers adjacent to the study area, which altogether reached $1,661 \mathrm{~m}^{3} \mathrm{~s}^{-1}$ (Fig. 2c). As the mooring lines were not yet deployed, we cannot investigate the impact of this eastern storm on the sediment transport downcanyon.

The following months were characterized by the occurrence of cold and dry northern windstorms. Cumulative turbulent heat fluxes from the beginning of November 2010 to late December 2010 were about $400 \mathrm{~W} \mathrm{~m}^{-2}$ higher than during the same months in the previous winter. Heat loss triggered a loss of buoyancy and the occurrence of DSWC along the submarine canyon. In fact, it seems that there is a certain heat loss threshold above which DSWC occurs, as can be seen when comparing the two winters evaluated (Fig 3ab). During the first winter it was not until turbulent heat fluxes (Fig. 3c) reached values of about $6 \times 10^{3} \mathrm{~W} \mathrm{~m}^{-2}$ that the first DSWC event occurred. The same happened during winter 2010-2011 - the first dense shelf water pulse was recorded, as a near-bottom water temperature drop, when winter cumulative turbulent heat fluxes reached values of around $6 \times 10^{3} \mathrm{~W} \mathrm{~m}^{-2}$ (Fig. 3c).

The DSWC event of December 2010 lasted for 17 days and triggered increased current speeds. The consequences of this event were a rapid but discrete increase in the current speed, SSC and TMF in the canyon head (Fig. 2e-g). Furthermore, the newly formed water plume became dense enough to cascade along the canyon, reaching depths of at least $1000 \mathrm{~m}$ as the TMF of the CC1000 recorded values of approximately $16.6 \mathrm{~g} \mathrm{~m}^{-2} \mathrm{~d}^{-1}$ (Fig. $2 \mathrm{~g}$ ).

Turbulent heat losses from the beginning of January until March 2011 were lower than the previous 2009-2010 winter. Furthermore, the increased river discharge recorded in the Rhône River throughout winter, together with the punctual discharge from the smaller rivers opening to the Gulf of Lions, suggest the presence of a large amount of light 
freshwater in the shelf. This might have inhibited dense water formation through increased buoyancy of surface waters.

In late January 2011 a slight temperature drop indicates the arrival of dense shelf waters. The occurrence of a concomitant eastern storm with $\mathrm{Hs}$ of up to $3.6 \mathrm{~m}$ suggests that the eastern storm reactivated punctually DSWC, despite the freshwater inhibition. Indeed it is well known that eastern storms cause intense shelf sediment resuspension, which can decrease buoyancy and form a downcanyon flow (Palanques et al., 2006; Sanchez-Vidal et al., 2012). This is demonstrated by the increased current speed $\left(0.71 \mathrm{~m} \mathrm{~s}^{-1}\right)$, SSC (11.02 $\mathrm{mg} \mathrm{L}^{-1}$ ) and TMF (up to $29.0 \mathrm{~g} \mathrm{~m}^{-2} \mathrm{~d}^{-1}$ ) at the canyon head. The turbid flow might have stopped before reaching the $\mathrm{CC} 1000$ station as no significant TMF increase was recorded. The grain size of the samples collected during this event presented a clear coarsening at $\mathrm{CC} 300$ but not at CC1000 (Fig. 6b).

In mid-March 2011, another eastern storm occurred, with Hs of more than $4.5 \mathrm{~m}$, which was accompanied by a significant increase in the Massif Central and Pyrenees rivers discharge (Figs. 2c, 3d). Increased current speeds (up to $0.68 \mathrm{~m} \mathrm{~s}^{-1}$ ) and SSC (up to $7.37 \mathrm{mg} \mathrm{L}^{-1}$ ) were recorded. The fact that flooding occurred several days after the main pulse of downcanyon sediment transport suggest again, that erosion from the adjacent shelf was the main source of particles introduced in the canyon during mid-March 2011 (Martín et al., 2013). The turbid flow did not penetrate into the canyon deeper than about $350 \mathrm{~m}$. The coarsening of the grain size of the particles collected at CC300 suggest that near-bottom currents during this event where strong enough to resuspend and transport coarse particles in suspension from the shelf to the canyon head (Fig. 6b).

\subsection{Variability in composition of the settling particles and $\mathrm{Chl} a$}

\subsubsection{Principal variations in the composition of the settling particles of winter-spring 2009-2010}

Winter 2009-2010 dense shelf water pulses caused TMF to increase and to be dominated by the siliciclastic fraction (more than 67\%) (Fig. 5). During December 2009, and January and February 2010, the composition of the settling particles was relatively constant, showing that DSWC pulses transported homogenized materials from the same origin (i.e. the shelf and upper slope) towards the basin (as reported before by Pasqual et al. (2010)). Furthermore, during these events, the non-siliciclastic fraction was close to the values reported by Heussner et al. (2006), with $\sim 20$ $30 \% \mathrm{CaCO}_{3}, 2-3 \% \mathrm{OM}$, and opal was virtually absent. These values were also close to those reported by Roussiez et al. (2006) for the superficial sediments from the shelf and upper slope $\left(31 \% \mathrm{CaCO}_{3}, 1-4 \% \mathrm{OM}\right.$ and opal nearly absent or under detection limit).
In the end of the winter and beginning of spring, the changes in the composition of the settling particles responded to a seasonal control. The higher variability in the biological signal (i.e. OM and opal content) occurred in response to the biological spring bloom recorded during March and April 2010 (Fig. 4). The less severe hydrodynamic conditions (end of the major cascading pulse) also favored the reduction of the input of resuspended lithogenic particles.

The $\mathrm{CaCO}_{3}$ relative abundance displayed an apparently random pattern with higher values in January and February 2010, which are not related to OM and opal peaks (Fig. 5). The resuspension and transport of carbonated shell remains from the shelf is the most plausible explanation, as suggested by Martín et al. (2006) in the nearby La Fonera submarine canyon (Fig. 1).

\subsubsection{Composition variability of settling particles during winter-spring 2010-2011}

In the context of a milder and wetter 2010-2011 winterspring period, the high lithogenic fraction in settling particles suggests also a dominant resuspended origin, especially in the shallower station, which was the more affected by the main sediment transport events. However, primary production products (i.e. OM and opal) dilution due to increased lithogenic sediments resuspension was lower, most likely because of the weakened main transport events. This was also evident in the relative abundance of $\mathrm{CaCO}_{3}$ and especially at the CC1000 station, which was impacted by less events than the preceding winter and spring. Nevertheless, at CC300 the $\mathrm{CaCO}_{3}$ relative abundance decreased progressively until the end of February 2011. At the same time, an increase of $\mathrm{OM}$ and lithogenic contributions were recorded, which in absence of any primary production event suggests the arrival of OM-rich resuspended material. The occurrence of a weakened dense shelf water cascading may have triggered a selective winnowing of fine (and OC-rich, following Tesi et al., 2010 and Sanchez-Vidal et al., 2008) particles (Ferré et al., 2005; Bourrin et al., 2008) that sedimented in the head of the canyon. The development of the phytoplanktonic bloom in spring 2011 (Fig. 4) may have increased the contribution of $\mathrm{CaCO}_{3}$, together with $\mathrm{OM}$ and opal to maximum levels (Fig. 5).

\section{Conclusions}

This study compares hydro-sedimentary processes and associated particle fluxes in the westernmost submarine canyon of the Gulf of Lions, at the outlet of the shelf and slope cyclonic circulation system of the area, during the winters and part of the springs of 2009-2010 and 2010-2011. During these periods, contrasting atmospheric forcings developed and led to unequal modifications of the thermohaline properties of the upper ocean layer. 
A more pronounced ocean-to-atmosphere heat transfer (up to $14.2 \times 10^{3} \mathrm{~W} \mathrm{~m}^{-2}$ ) occurred in winter 2009-2010, which triggered a stronger cooling of the water over the continental shelf, compared to winter 2010-2011. This situation resulted in an increase in the density of surface water, which sank and cascaded at higher velocities (up to $0.99 \mathrm{~m} \mathrm{~s}^{-1}$ ) down the Cap de Creus canyon. The higher current speeds recorded during winter 2009-2010 caused higher erosion, resuspension and ultimately transport of sediment to the midcanyon reach. In contrast, reduced heat losses were recorded $\left(12.6 \times 10^{3} \mathrm{~W} \mathrm{~m}^{-2}\right)$ during winter $2010-2011$, which, together with a high volume of cumulated freshwater over the shelf, inhibited the penetration of dense shelf water down to the middle canyon. A noticeable eastern storm that occurred during this winter-spring, resulted in peak near-bottom currents of $0.68 \mathrm{~m} \mathrm{~s}^{-1}$ at $300 \mathrm{~m}$ and the export of particles only down to the upper canyon reach.

The lithogenic fraction was dominant in the particle fluxes of the two winter-spring seasons, which point to a resuspension origin, despite the comparatively milder character of the 2010-2011 winter. The variability in OM and opal contents followed a seasonal pattern in response to the plankton spring bloom during March and April 2010 and 2011.

The $\mathrm{CaCO}_{3}$ relative abundance also showed a noticeable variability both within each winter-spring and between the two winter-spring periods. Variability sources are, however, different. The apparently random pattern of $\mathrm{CaCO}_{3}$ in 20092010 is attributed to the resuspension of relict carbonate shells during the multi-pulse, deep-penetrating DSWC of that winter. In contrast, the weakened transport events during winter-spring 2010-2011 triggered the resuspension of only fine (and OM-rich) particles. Furthermore, the lower advection of resuspended sediments favored an increase in the relative content of the biogenic components (OM, opal and $\mathrm{CaCO}_{3}$ ) during the spring bloom.

These results confirm that DSWC plays a key role in governing the timing, composition and volumes of particle fluxes that are exported down Cap de Creus canyon, while eastern storms similar to the one recorded in winter-spring 2010 2011 can also contribute to enhance erosion, resuspension and the off-shelf transport of particles independently of the occurrence of DSWC.

Acknowledgements. This research has been supported by the ECfunded HERMIONE (FP7-ENV-2008-1-226354) and PERSEUS RTD projects (FP7 287600), and by the Spanish projects GRACCIE (CSD2007-00067) and DOS MARES (CTM2010-21810-C03-01). J. Martin was funded through a JAE-DOC contract within the Program "Junta Para la Ampliación de Estudios", granted by Consejo Superior de Investigaciones Científicas and co-financed by the European Social Fund. Generalitat de Catalunya is acknowledged for support to GRC Marine Geosciences through its Grups de Recerca Consolidats grant 2009 SGR 1305. We thank D. Amblas and the crew of the vessels Lluerna and Felipe for their dedication during mooring operations. We also thank M. Guart for helping with the laboratory work, X. Rayo for his technical assistance when using Geographic Information Systems, A. Micallef for improving the English, and two anonymous referees for their valuable comments.

Edited by: R. Danovaro

\section{References}

Bourrin, F. and Durrieu de Madron, X.: Contribution of the study of coastal rivers and associated prodeltas to sediment supply in north-western Mediterranean Sea (Gulf of Lions), Vie Milieu, 56, 307-314, 2006.

Bourrin, F., Durrieu de Madron, X., Heussner, S., and Estournel, C.: Impact of winter dense water formation on shelf sediment erosion (evidence from the Gulf of Lions, NW Mediterranean), Cont. Shelf Res., 28, 1984-1999, doi:10.1016/j.csr.2008.06.006, 2008.

Canals, M., Casamor, J. L., Urgeles, R., Farrán, M., Calafat, A. M., Amblas, D., Willmott, V., Estrada, F., Sánchez, A., Arnau, P., Frigola, J., and Colás, S.: Mapa del relleu submarí de Catalunya, 1:250 000; Institut Cartogràfic de Catalunya, Barcelona, Spain, 1 map, 2004.

Canals, M., Puig, P., Durrieu de Madron, X., Heussner, S., Palanques, A., and Fabres, J.: Flushing submarine canyons, Nature, 444, 354-357, doi:10.1038/nature05271, 2006.

Company, J. B., Puig, P., Sardà, F., Palanques, A., Latasa, M., and Scharek, R.: Climate influence on deep sea populations, PloS one, 3, e1431, doi:10.1371/journal.pone.0001431, 2008.

Deser, C., Alexander, M. A., Xie, S.-P., and Phillips, A. S.: Sea Surface Temperature Variability: Patterns and Mechanisms, Ann. Rev. Mar. Sci., 2, 115-143. doi:10.1146/annurev-marine120408-151453, 2010.

Durrieu de Madron, X., Zervakis, V., Theocharis, A., and Georgopoulos, D.: Comments to "Cascades of dense water around the world ocean”, Progr. Oceanogr., 64, 83-90, doi:10.1016/j.pocean.2004.08.004, 2005.

Estrada, M.: Primary production in the Northwestern Mediterranean, Sci. Mar. 60, 55-64, 1996.

Fabres, J., Tesi, T., Velez, J., Batista, F., Lee, C., Calafat, A., Heussner, S., Palanques, A., and Miserocchi, S.: Seasonal and eventcontrolled export of organic matter from the shelf towards the Gulf of Lions continental slope, Cont. Shelf Res., 28, 19711983, doi:10.1016/j.csr.2008.04.010, 2008.

Ferré, B., Guizien, K., Durrieu de Madron, X., Palanques, A., Guillén, J., and Grémare, A.: Fine-grained sediment dynamics during a strong storm event in the inner-shelf of the Gulf of Lion (NW Mediterranean), Cont. Shelf Res., 25, 2410-2427, doi:10.1016/j.csr.2005.08.017, 2005.

Guillén, J., Palanques, A., Puig, P., Durrieu de Madron, X., and Nyffeler, F.: Field calibration of optical sensors for measuring suspended sediment concentration in the Western Mediterranean, Sci. Mar., 64, 427-435, 2000.

Guillén, J., Bourrin, F., Palanques, a, Durrieu de Madron, X., Puig, P., and Buscail, R.: Sediment dynamics during wet and dry storm events on the Têt inner shelf (SW Gulf of Lions), Mar. Geol., 234, 129-142, doi:10.1016/j.margeo.2006.09.018, 2006.

Heussner, S., Ratti, C., and Carbonne, J.: The PPS 3 time-series sediment trap and the trap sample processing techniques used 
during the ECOMARGE experiment, Cont. Shelf Res., 10, 943958, doi:10.1016/0278-4343(90)90069-X, 1990.

Heussner, S., Durrieu de Madron, X., Calafat, A., Canals, M., Carbonne, J., Delsaut, N., and Saragoni, G.: Spatial and temporal variability of downward particle fluxes on a continental slope: Lessons from an 8-yr experiment in the Gulf of Lions (NW Mediterranean), Mar. Geol., 234, 63-92, doi:10.1016/j.margeo.2006.09.003, 2006.

Ivanov, V. V., Shapiro, G. I., Huthnance, J. M., Aleynik, D. L., and Golovin, P. N.: Cascades of dense water around the World Ocean. Progr. Oceanogr., 60, 47-98, doi:10.1016/j.pocean.2003.12.002, 2004.

Josey, S. A.: Changes in the heat and freshwater forcing of the eastern Mediterranean and their influence on Deep Water Formation, J. Geophys. Res., 108, 3237, doi:10.1029/2003JC001778, 2003.

Josey, S. A., Kent, E. C., and Taylor, P. K.: New insights into the ocean heat budget closure problem from analysis of the SOC airsea flux climatology, J. Clim., 12, 2856-2880, doi:10.1175/15200442(1999)012<2856:NIITOH > 2.0.CO;2, 1999.

Lastras, G., Canals, M., Urgeles, R., Amblas, D., Ivanov, M., Droz, L., Dennielou, B., Fabrés, J., Schoolmeester, T., Akhmetzhanov, A., Orange, A., and García-García, A.: A walk down the Cap de Creus canyon, Northwestern Mediterranean Sea: Recent processes inferred from morphology and sediment bedforms, Mar. Geol., 246, 176-192. doi:10.1016/j.margeo.2007.09.002, 2007.

Ludwig, W., Meybeck, M., and Abousamra, F.: Riverine transport of water, sediments, and pollutants to the Mediterranean Sea, UNEP MAP Technical report Series 141, UNEP/MAP Athens, 111 pp., 2003.

Martín, J., Palanques, A., and Puig, P.: Composition and variability of downward particulate matter fluxes in the Palamós submarine canyon (NW Mediterranean), J.Mar. Sys., 60, 75-97, 2006.

Martín, J., Miquel, J. C., and Khripounoff, A.: Impact of open sea deep convection on sediment remobilization in the western Mediterranean, Geophys. Res. Lett., 37, L13604, doi:10.1029/2010GL043704, 2010.

Martín, J., Durrieu de Madron, X., Puig, P., Bourrin, F., Palanques, A., Houpert, L., Higueras, M., Sanchez-Vidal, A., Calafat, A. M., Canals, M., Heussner, S., Delsaut, N., and Sotin, C.: Sediment transport along the Cap de Creus Canyon flank during a mild, wet winter, Biogeosciences, 10, 3221-3239, doi:10.5194/bg-103221-2013, 2013.

Martín-Vide, J. and Raso Nadal, J. M.: Atlas climàtic de Catalunya, Període 1961-1990, Institut Cartogràfic de Catalunya, Barcelona, 2008.

MEDOC Group: Observation of formation of deep water in the Mediterranean Sea, 1969, Nature, 227, 1037-1040, doi:10.1038/2271037a0, 1970.

Millot, C. A.: The Gulf of Lions' hydrodynamic. Cont. Shelf Res., 10, 885-894, 1990.Millot, C., Circulation in the Western Mediterranean Sea, J. Mar. Sys., 20, 423-442, 1999.

Mortlock, R. A. and Froelich, P. N.: A simple method for the rapid determination of biogenic opal in pelagic marine sediments, Deep-Sea Res., 36, 1415-1426, 1989.

Palanques, A., Durrieu de Madron, X., Puig, P., Fabres, J., Guillén, J., Calafat, A., Canals, M., Heussner, S., and Bonnin, J.: Suspended sediment fluxes and transport processes in the Gulf of Lions submarine canyons, The role of storms and dense water cascading, Mar. Geol., 234, 43-61. doi:10.1016/j.margeo.2006.09.002, 2006.

Palanques, A., Guillén, J., Puig, P., and Durrieu de Madron, X.: Storm-driven shelf-to-canyon suspended sediment transport at the southwestern Gulf of Lions, Cont. Shelf Res., 28, 19471956, doi:10.1016/j.csr.2008.03.020, 2008.

Palanques, A., Puig, P., Durrieu de Madron, X., Sanchez-Vidal, A., Pasqual, C., Martín, J., Calafat, A., Heussner, S., and Canals, M.: Sediment transport to the deep canyons and open-slope of the western Gulf of Lions during the 2006 intense cascading and open-sea convection period, Progr. Oceanogr., 106, 1-15, 2012.

Pasqual, C., Sanchez-Vidal, A., Zúñiga, D., Calafat, A., Canals, M., Durrieu de Madron, X., Puig, P., Heussner, S., Palanques, A., and Delsaut, N.: Flux and composition of settling particles across the continental margin of the Gulf of Lion: the role of dense shelf water cascading, Biogeosciences, 7, 217-231, doi:10.5194/bg-7217-2010, 2010.

Puig, P., Palanques, A., Orange, D.L., Lastras, G., and Canals, M.: Dense shelf water cascading and furrows formation in the Cap de Creus Canyon, northwestern Mediterranean Sea, Cont. Shelf Res., 28, 2017-2030, 2008.

Pusceddu, A., Bianchelli, S., Canals, M., Sanchez-Vidal, A., Durrieu De Madron, X., Heussner, S., Lykousis, V., de Stigter, H., Trincardi, F., and Danovaro, R.:Organic matter in sediments of canyons and open slopes of the Portuguese, Catalan, Southern Adriatic and Cretan Sea margins, Deep-Sea Res., 57, 441-457, doi:10.1016/j.dsr.2009.11.008, 2010.

Roussiez, V., Ludwig, W., Monaco, A., Probst, J.L., Bouloubassi, I., Buscail, R., and Saragoni, G.: Sources and sinks of sedimentbound contaminants in the Gulf of Lions (NW Mediterranean Sea): A multi-tracer approach, Cont. Shelf Res., 26, 1843-1857, doi:10.1016/j.csr.2006.04.010, 2006.

Salvadó, J. A., Grimalt, J. O., López, J. F., Durrieu de Madron, X., Heussner, S., and Canals, M.: Transformation of PBDE mixtures during sediment transport and resuspension in marine environments (Gulf of Lion, NW Mediterranean Sea), Environ. Pollut., 168, 87-95, doi:10.1016/j.envpol.2012.04.019, 2012.

Sanchez-Vidal, A., Pascual, C., Kerhervé, P.A., Calafat, A., Heussner, S., Palanques, A., Durrieu de Madron, X., Canals, M., and Puig. P: Impact of dense shelf water cascading on the transfer of organic matter to the deep Western Mediterranean Basin, Geophys. Res. Lett., 35, L05605, doi:10.1029/2007GL032825, 2008.

Sanchez-Vidal, A., Pasqual, C., Kerhervé, P., Heussner, S., Calafat, A., Palanques, A., Durrieu de Madron, X., Canals, M., and Puig, P.: Across margin export of organic matter by cascading events traced by stable isotopes northwestern Mediterranean Sea, Limnol. Oceanogr., 54, 1488-1500, 2009.

Sanchez-Vidal, A., Canals, M., Calafat, A., Lastras, G., PedrosaPàmies, R., Menéndez, M., Medina, R., Company, J. B., Hereu, B., Romero. J., and Alcoverro, T.: Impacts on the Deep-Sea Ecosystem by a Severe Coastal Storm, PLoS one, 7, e30395, doi:10.1371/journal.pone.0030395, 2012.

Schroeder, K., Josey, S. A., Herrmann, M., Grignon, L., Gasparini, G. P., and Bryden, H.L.: Abrupt warming and salting of the Western Mediterranean Deep Water: Atmospheric forcings and lateral advection, J. Geophys. Res., 115, C08029, doi:10.1029/2009JC005749, 2010.

Serrat, P., Ludwig, W., Navarro, B., and Blazi, J.L.: Variabilité spatio-temporelle des flux de matières en suspension d'un fleuve côtier méditerranéen: la Têt (France), Spatial and temporal 
variability of sediment fluxes from a coastal Mediterranean river: the Têt (France), Cr. Acad. Sci. IIA, 333, 389-397, doi:10.1016/S1251-8050(01)01652-4, 2001.

Tesi, T., Puig, P., Palanques, A., and Goñi, M. A.: Lateral advection of organic matter in cascading-dominated submarine canyons, Progr. Oceanogr., 84, 185-203, doi:10.1016/j.pocean.2009.10.004, 2010.
Ulses, C., Estournel, C, Bonnin, J., Durrieu de Madron, X., and Marsaleix, P.: Impact of storms and dense water cascading on shelf-slope exchange in the Gulf of Lions (NW Mediterranean), J. Geophys. Res., 113, CO2010, doi:10.1029/2006JC003795, 2008a.

Ulses, C., Estournel, C., Durrieu de Madron, X., and Palanques, A.: Suspended sediment transport in the Gulf of Lion (NW Mediterranean): impact of extreme storms and floods, Cont. Shelf Res., 28, 2048-2070, doi:10.1016/j.csr.2008.01.015, 2008b. 